\title{
PENGARUH RASIO ENERGI DAN PROTEIN YANG BERBEDA TERHADAP EFISIENSI PEMANFAATAN PROTEIN PADA BENIH BAUNG (Mystus nemurus C.V.)
}

\author{
Yanti Suryanti, Agus Priyadi, dan Honorius Mundriyanto
}

\begin{abstract}
ABSTRAK
Ikan baung adalah jenis ikan yang tersebar di beberapa perairan sungai di Sumatera, Jawa, dan Kalimantan. Jenis ikan ini mulai dibudidayakan dengan benih ikan alam. Tujuan penelitian ini adalah untuk mengetahui rasio energi-protein optimum yang dibutuhkan oleh benih baung. Penelitian terdiri atas 2 kelompok, di mana masing-masing menggunakan pakan berkadar protein berbeda dengan rasio energi-protein sama yaitu: $(30 \% ; 6),(35 \% ; 6),(40 \% ; 6)$ dan $(30 \% ; 8)$, $(35 \% ; 8),(40 \% ; 8)$. Setiap perlakuan dikenakan 3 kali ulangan. Bobot rata-rata awal ikan uji adalah $0,28 \mathrm{~g}$ (umur 19 hari) yang dipelihara dalam akuarium dengan volume $100 \mathrm{~L}$. Padat penebaran ikan 100 ekor/akuarium. Jumlah pakan ditentukan secara ad-libitum, diberikan 4 kali/hari. Berdasarkan pada laju pertumbuhan, efisiensi pakan, rasio efisiensi protein, retensi protein, dan lemak, maka benih baung membutuhkan pakan dengan protein 35\% dengan rasio energi-protein $8 \mathrm{kkal} / \mathrm{g}$ protein.
\end{abstract}

\begin{abstract}
Effect of different energy-protein ratios on protein utilization efficiency of baung fry (Mystus nemurus C.V.). By: Yanti Suryanti, Agus Priyadi, and Honorius Mundriyanto

The aim of this experiment was to know energy-protein ratio required by baung fry. Divided into two experimental groups; fish were given feeds containing different protein level but the same energy-protein ratio: $(30 \% ; 6),(35 \% ; 6),(40 \% ; 6)$ and $(30 \% ; 8),(35 \% ; 8),(40 \% ; 8)$, each treatment had three replications. Fish with $0.28 \mathrm{~g}$ initial body weight (19 days old) were reared in $100 \mathrm{~L}$ aquaria with stocking density of 100 fish/aquaria. Ad-libitum feeding was given four times daily. Based on the daily growth rate, feed efficiency, protein efficiency ratio, and protein-fat retention, baung fry required feed with $35 \%$ protein level and energy-protein ratio of $8 \mathrm{kcal} / \mathrm{g}$ protein.
\end{abstract}

KEYWORDS: protein requirement, energy-protein ratio, baung, fry, Mystus nemurus

\section{PENDAHULUAN}

Ikan baung (Mystus nemurus C.V.) merupakan salah satu jenis ikan lokal yang terdapat di beberapa perairan sungai di Sumatera, Jawa, dan Kalimantan. Pada tahun 1980 ikan baung mulai dibudidayakan baik di kolam maupun di sangkar bambu (keramba) dengan menggunakan benih dari tangkapan di alam. Dalam budi dayanya, ikan baung sangat mudah beradaptasi terhadap pakan buatan dan dalam relatif singkat ( 6 bulan) dapat mencapai ukuran konsumsi.

Dengan berkembangnya usaha budi daya ikan baung, maka kebutuhan terhadap benih semakin meningkat dan tentunya tidak bisa tergantung hasil tangkapan dari alam. Walaupun ikan ini sudah dapat dipijahkan secara buatan dengan menggunakan stimulasi hormon, produksi benih masih sangat terbatas antara 30\%--40\% dari jumlah telur yang dihasilkan (Mardiyati, 1997 dalam Tang, 2000). Rendahnya tingkat sintasan dan pertumbuhan pada stadia benih ikan baung disebabkan terutama oleh pakan yang tidak sesuai dengan kebutuhan benih baung. Untuk menyusun kualitas pakan yang baik bagi ikan baung, diperlukan pengetahuan mengenai kebutuhan nutrisinya. Sampai saat ini penelitian mengenai kebutuhan nutrisi ikan baung belum banyak dilakukan.

Salah satu nutrien penting yang dibutuhkan ikan adalah protein, karena merupakan zat pakan yang sangat diperlukan bagi pertumbuhan (Khans et al., 1973). Pemanfaatan protein bagi pertumbuhan ikan dipengaruhi oleh beberapa faktor antara lain ukuran, umur, kualitas protein, kandungan energi pakan, suhu air, dan tingkat pemberian pakan (NRC, 1983). Protein merupakan nutrien yang relatif mahal dibandingkan dengan nutrien lainnya. Oleh karena itu keseimbangan antara protein dan sumber energi non protein, seperti lemak dan karbohidrat dalam pakan dapat berperan sebagai sparing effect dari protein.

Peneliti pada Balai Riset Perikanan Budidaya Air Tawar, Bogor 
Menurut Watanabe (1988), pertumbuhan hanya dapat terjadi jika kebutuhan energi untuk pemeliharaan proses-proses hidup dan fungsi-fungsi lain sudah terpenuhi. Jadi pakan harus mempunyai rasio energi protein tertentu, yang dapat menyediakan energi non protein dalam jumlah cukup, supaya protein pakan sebagian besar digunakan untuk pertumbuhan (Wilson, 1985).

Berdasarkan permasalahan tersebut maka perlu dilakukan kajian secara mendalam khususnya efisiensi protein melalui rasio protein energi yang dapat mendukung sintasan dan pertumbulan benih yang tinggi. Oleh karena itu tujuan penelitian ini adalah untuk mengetahui rasio energi-protein optimun yang dibutuhkan oleh benih ikan baung, berdasarkan pemanfaatan protein oleh benih ikan baung.

\section{BAHAN DAN METODE}

Penelitian dilakukan di Instalasi Riset Budidaya Ikan Hias Air Tawar, Depok. Penelitian dibagi dalam 2 kelompok, masing-masing kelompok menggunakan kadar protein berbeda tetapi rasio energi-protein sama. Setiap kelompok penelitian terdiri atas 2 ulangan seperti tertera pada Tabel 1.

Ikan uji yang digunakan adalah benih ikan baung dengan bobot rata-rata 0,28g/individu (umur 19 hari). Ikan dipelihara dalam akuarium volume $100 \mathrm{~L}$ sebanyak 18 buah yang dilengkapi sistem resirkulasi dan aerasi dengan padat penebaran 100 ekor/ akuarium. Frekuensi pemberian pakan adalah 4 kali/ hari dan jumlah pakan ditentukan secara 'ad-libitum'. Formulasi pakan uji disajikan pada Tabel 2. Penelitian dilakukan selama 30 hari dan penimbangan bobot ikan dilakukan setiap 10 hari. Analisis proksimat ikan uji dilaksanakan pada awal dan akhir penelitian, sedangkan bahan baku dan pakan uji dilakukan pada awal penelitian (Tabel 3). Rancangan yang digunakan adalah rancangan acak lengkap. Analisis data menggunakan analisis ragam yang diteruskan dengan polinomial orthogonal.

Tabel 1. Kelompok penelitian berdasarkan rasio energi-protein dan kadar protein yang berbeda untuk benih baung

Table 1. The experimental group based on energy-protein ratio and different protein level for fry baung

\begin{tabular}{ccccc}
\hline $\begin{array}{c}\text { Kelompok penelitian } \\
\text { Experimental group }\end{array}$ & $\begin{array}{c}\text { Rasio energi-protein (kkal/g protein) } \\
\text { Energy-protein ratio (kcal/g protein) }\end{array}$ & $\begin{array}{c}\text { Kadar protein (\%) } \\
\text { Protein level (\%) }\end{array}$ \\
\hline 1 & 6 & 30 & 35 & 40 \\
$\|$ & 8 & 30 & 35 & 40 \\
\hline
\end{tabular}

Parameter yang diukur:

a. Laju pertumbuhan harian: $W t=W_{0}(1+0,01 \alpha) t($ Huisman, 1976)

Wt : bobot akhir

Wo : bobot awal

$\propto$ : laju pertumbuhan

$\mathrm{t}$ : lama penelitian

b. Rasio efisiensi protein: $\frac{\text { Pertambaha } n \text { bobot }(\mathrm{g})}{\text { gprotein dalam pakan }}$ (De Silva et al., 1995)

c. Efisiensi pakan: $\frac{\text { Pertambahan bobot }(\mathrm{g})}{\text { Jumlah pakan yang diberikan }(\mathrm{g})} \times 100 \%$

d. Retensi protein dan lemak (Viola \& Rappaport, 1979)

Retensi protein $=\frac{\text { Bobot protein tubuh akhir }- \text { Bobot protein tubuh awal }}{\text { Bobot protein yang dimakan }} \times 100 \%$
Retensi lemak $=\frac{\text { Bobot lemak tubuh akhir }- \text { Bobot lemak tubuh awal }}{\text { Bobot lemak yang dimakan }} \times 100 \%$ 
Tabel 2. Formulasi pakan uji yang digunakan untuk setiap kelompok penelitian

Table 2. Formulation of the experimental diets used for each group experiment

\begin{tabular}{|c|c|c|c|c|c|c|}
\hline \multirow{3}{*}{$\begin{array}{l}\text { Bahan baku (\%) } \\
\text { Ingredients (\%) }\end{array}$} & \multicolumn{6}{|c|}{ Kelompok penelitian (Experimental group) } \\
\hline & \multicolumn{3}{|c|}{6} & \multicolumn{3}{|c|}{8} \\
\hline & 30 & 35 & 40 & 30 & 35 & 40 \\
\hline Tepung ikan (Fish meal) & 29 & 30 & 35 & 25 & 30 & 40 \\
\hline Tepung rebon (Shrimp meal) & 30 & 25 & 29 & 20 & 25 & 30 \\
\hline Terigu (Wheat) & 19.50 & 30 & 30 & 38.50 & 30 & 5 \\
\hline Campuran vitamin $(\text { Vitamin mix })^{\star}$ & 2 & 2 & 2 & 2 & 2 & 2 \\
\hline Campuran mineral (Mineral mix) ${ }^{\star}$ & 1 & 1 & 1 & 1 & 1 & 1 \\
\hline Minyak ikan (Fish oil) & 2 & 0.75 & 1.50 & 3 & 5 & 8 \\
\hline Minyak jagung (Corn oil) & 2 & 0.75 & 1.50 & 3 & 5 & 8 \\
\hline a-selulosa (a-celulose) & 14.50 & 10.50 & 0 & 7.50 & 2 & 6 \\
\hline \multicolumn{7}{|l|}{ Hasil perhitungan: (Calculation result:) } \\
\hline Kadar protein (\%) (Protein level) & 30.3 & 35.04 & 40.10 & 30.50 & 35.04 & 40.30 \\
\hline Energi (kkal) (Energy) & $1,873.72$ & $2,171.2$ & 2,490 & $2,477.9$ & $2,859.70$ & $3,271.17$ \\
\hline Rasio energi-protein (Energy-protein ratio) & 6.20 & 6.20 & 6.20 & 8.10 & 8.20 & 8.10 \\
\hline
\end{tabular}

Tabel 3. Komposisi hasil proksimat pakan uji

Table 3. The proximate composition of the experimental diets

\begin{tabular}{|c|c|c|c|c|c|c|}
\hline \multirow{3}{*}{$\begin{array}{l}\text { Komposisi (\%) } \\
\text { Composition (\%) }\end{array}$} & \multicolumn{6}{|c|}{ Kelompok penelitian (Experimental group) } \\
\hline & \multicolumn{3}{|c|}{6} & \multicolumn{3}{|c|}{8} \\
\hline & 30 & 35 & 40 & 30 & 35 & 40 \\
\hline Protein (Crude protein) & 30.58 & 35.22 & 40.10 & 30.72 & 35.45 & 40.30 \\
\hline Lemak (Crude fat) & 0.51 & 1.12 & 5.39 & 2.75 & 12.91 & 18.59 \\
\hline Abu (Ash) & 16.07 & 14.53 & 17.61 & 9.77 & 12.46 & 12.95 \\
\hline Serat kasar (Fibre) & 2.38 & 2.94 & 2.48 & 2.38 & 2.39 & 2.97 \\
\hline BETN (Nitrogen free extract) & 47.23 & 42.55 & 34.42 & 54.38 & 30.6 & 25.21 \\
\hline $\begin{array}{l}\text { Energi }(k k a l)^{\star} \\
\text { Digestible energy (kcal) }\end{array}$ & $1,802.59$ & $2,202.19$ & $2,500.09$ & $2,503.85$ & $2,874.2$ & $3,343.42$ \\
\hline $\begin{array}{l}\text { Rasio kalori-protein } \\
\text { Energy-protein ratio }\end{array}$ & 6.01 & 6.25 & 6.23 & 8.15 & 8.11 & 8.29 \\
\hline
\end{tabular}

* hasil perhitungan: NRC (1977): $1 \mathrm{~g}$ protein $=3,0 \mathrm{kcal}$ digestible energy, $1 \mathrm{~g}$ lemak $=8,1 \mathrm{kcal}$ digestible energy, $1 \mathrm{~g}$ karbohidrat $=2,5 \mathrm{kcal}$ digestible energy

\section{HASIL DAN BAHASAN}

Hasil penelitian tahap I mengenai rasio energi-protein $6 \mathrm{kkal} / \mathrm{g}$ protein pada kadar protein yang berbeda disajikan pada Tabel 4.

Laju pertumbuhan biomassa harian dan efisiensi pakan dari masing-masing perlakuan tidak menunjukkan perbedaan yang nyata $(P>0,05)$. Hal ini diduga waktu penelitian relatif singkat sehingga untuk pertumbuhan belum nyata berbeda.
Rasio efisiensi protein yang dihasilkan meningkat dengan bertambahnya kandungan protein yang ditunjukkan oleh persamaan $Y=-0,41+0,04 x(Y=$ rasio efisiensi protein; $x=$ kadar protein). Demikian pula retensi protein juga meningkat dengan adanya peningkatan kadar protein pakan, yang ditunjukkan oleh persamaan $Y=-7,49+0,729 x$. Peningkatan nilai tersebut selain karena kandungan proteinnya meningkat juga total energi pakan yang tersedia meningkat walaupun rasio energi proteinnya sama 
untuk ketiga perlakuan pakan tersebut (Tabel 3). Hal ini berarti bahwa protein pakan yang tersedia bagi sintesis protein tinggi, sehingga protein yang dapat digunakan untuk pertumbuhan dan disimpan dalam tubuh makin besar.

Di samping itu, dengan meningkatnya energi nonprotein yang tersedia, maka bagian protein yang dikatabolisme untuk memenuhi kebutuhan energi tubuh juga lebih kecil. Keadaan ini akan menyebabkan banyaknya protein yang disimpan dalam tubuh semakin meningkat seperti digambarkan pada respon retensi protein. Menurut Lovell (1980), kebutuhan energi untuk hidup pokok harus dipenuhi terlebih dahulu sebelum energi pakan dapat disediakan untuk pertumbuhan. Jika kandungan energi pakan rendah maka sebagian besar protein pakan akan cikatabolisme untuk memenuhi kebutuhan energi ikan. Sebaliknya jika energi pakan terlalu tinggi maka ikan akan makan sejumlah kecil pakan tersebut, hal ini akan membatasi pertumbuhan ikan (Cowey \& Sargent, 1972; NRC, 1983). Jadi pakan harus mempunyai rasio energi yang dapat menyediakan energi nonprotein dalam jumlah yang cukup, supaya protein pakan sebagian besar digunakan untuk pertumbuhan (Wilson, 1985). Dari data rasio efisiensi protein dan retensi protein yang dihasilkan, pada rasio energi protein 6 $\mathrm{kkal} / \mathrm{g}$ protein, terhadap perbedaan protein terus meningkat.

Retensi lemak menggambarkan banyak bagian lemak pakan yang disimpan dalam tubuh. Retensi lemak yang dihasilkan meningkat dengan bertambahnya kadar protein, ditunjukkan dengan persamaan $Y=-25,84+1,38 x$. Peningkatan retensi lemak ini karena total lemak yang tersedia dengan meningkatnya protein dalam pakan semakin tinggi dan sejalan dengan itu ketersediaan total energinya juga meningkat. Dengan demikian kelebihan energi baik dari lemak maupun karbohidrat akan disimpan dalam tubuh sebagai simpanan lemak yang digambarkan oleh respon retensi lemak.

Sintasan benih ikan baung pada perlakuan protein $30 \%$ adalah $66 \%$, sedangkan pada protein $35 \%$ dan $40 \%$ adalah $76 \%$. Untuk pembenihan ikan baung ini sintasan yang diperoleh belum maksimal seperti yang telah dilakukan oleh Tang (2000) bahwa sintasan benih baung yang diperoleh selama pemeliharaan 30 hari adalah 74\%. Suryanti (2002) menyatakan bahwa hasil penelitian baung selama 40 hari menghasilkan sintasan tertinggi $79 \%$.

Hasil penelitian pada rasio energi-protein $8 \mathrm{kkal} / \mathrm{g}$ protein terhadap kadar protein yang berbeda disajikan pada Tabel 5.

Laju pertumbuhan biomassa harian ikan baung pada masing-masing perlakuan tidak menunjukkan perbedaan nyata $(P>0,05)$. Sedangkan efisiensi pakan meningkat dengan meningkatnya kadar protein sampai $37,10 \%$ menurut persamaan $Y=-426,715+25,672 x$ $-0,3441 x^{2}$. Hal ini sama dengan respon pada rasio efisiensi protein, yaitu meningkat dengan bertambahnya kadar protein sampai 35\%. Selanjutnya selaras dengan rasio efisiensi protein, maka retensi protein meningkat dengan bertambahnya kadar protein sampai 35,79\% menurut persamaan $Y=-183,451+$ $11,669 x-0,163 x^{2}$

Tabel 4. Performansi hasil penelitian benih baung pada rasio energi-protein $6 \mathrm{kkal} / \mathrm{g}$ protein pada kadar protein berbeda

Table 4. Performance of the experiment result baung fry at energy-protein ratio $6 \mathrm{kcal} / \mathrm{g}$ protein on different protein level

\begin{tabular}{|c|c|c|c|}
\hline \multirow[t]{2}{*}{$\begin{array}{l}\text { Parameter } \\
\text { Parameter }\end{array}$} & \multicolumn{3}{|c|}{$\begin{array}{l}\text { Perlakuan (kadar protein \%) } \\
\text { Treatment (protein level \%) }\end{array}$} \\
\hline & 30 & 35 & 40 \\
\hline Laju pertumbuhan biomas harian (\%) & $6.94 \pm 0.70$ & $6.98 \pm 0.35$ & $7.06 \pm 0.70$ \\
\hline $\begin{array}{l}\text { Daily biomass growth rate (\%) } \\
\text { Efisiensi pakan }(\%)\end{array}$ & $32.31 \pm 2.35$ & $35.05+1.65$ & \\
\hline $\begin{array}{l}\text { Efisiensi pakan (\%) } \\
\text { Feed efficiency (\%) }\end{array}$ & & & $37.04 \pm 2.08$ \\
\hline $\begin{array}{l}\text { Rasio efisiensi protein } \\
\text { Protein efficienci ratio }\end{array}$ & $0.78 \pm 0.11$ & $1.10 \pm 0.05$ & $1.19 \pm 0.01$ \\
\hline $\begin{array}{l}\text { Retensi protein }(\%) \\
\text { Protein retention (\%) }\end{array}$ & $14.28 \pm 1.26$ & $18.24 \pm 0.80$ & $21.57 \pm 1.30$ \\
\hline $\begin{array}{l}\text { Protein retention (\% } \\
\text { Retensi lemak }(\%)\end{array}$ & $15.37 \pm 1.58$ & $22.64 \pm 1.70$ & $29.15 \pm 1.88$ \\
\hline Fat retention (\%) & & & \\
\hline $\begin{array}{l}\text { Sintasan }(\%) \\
\text { Survival rate (\%) }\end{array}$ & 66 & 76 & 76 \\
\hline
\end{tabular}


Rendahnya retensi protein yang terjadi pada kadar protein $30 \%$ karena protein yang diberikan masih rendah untuk kebutuhan tubuh ikan, juga total energinya rendah. Hal ini berarti protein yang tersedia untuk disimpan rendah, sehingga rasio efisiensi protein juga rendah. Pada kadar protein $30 \%$ kandungan energi nonprotein yang tersedia lebih kecil dari perlakuan lainnya, sehingga bagian protein pakan yang digunakan sebagai sumber energi juga akan lebih banyak dari kadar protein $35 \%$ dan $40 \%$. Hal ini menyebabkan rendahnya efisiensi pakan, rasio efisiensi protein, dan retensi protein pada protein $30 \%$. Menurut Sveier et al. (1999) rendahnya efisiensi pakan pada kadar protein rendah terutama disebabkan oleh total energi pakan yang rendah.

Nilai efisiensi pakan, rasio efisiensi protein, dan retensi protein tertinggi diperoleh pada kadar protein $35 \%$. Hal ini menunjukkan bahwa energi non protein dalam pakan pada kadar protein tersebut tersedia dalam jumlah yang cukup, sehingga protein pakan sebagian besar digunakan untuk pertumbuhan. Berdasarkan Hernandez et al. (2001), keseimbangan rasio energi-protein akan mendorong ikan untuk menggunakan lemak dan karbohidrat sebagai sumber energi nonprotein.

Pada kadar protein pakan $40 \%$ respon pertumbuhan menurun karena kadar protein tersebut telah melebihi batas kebutuhan ikan akan protein, dan keadaan ini akan menyebabkan tingginya kebutuhan energi ikan untuk proses pembakaran protein pakan yang tidak digunakan untuk sintesis tubuh (Mokoginta, 1995). Menurut Gaylord (2001), bahwa konsumsi pakan dipengaruhi oleh kadar protein pakan. Keadaan ini akan membatasi jumlah pakan yang dikonsumsi ikan, sehingga membatasi jumlah protein yang dimakan, akibatnya retensi protein, rasio efisiensi protein, efisiensi pakan, dan laju pertumbuhan harian tidak lagi meningkat.

Retensi lemak semakin rendah dengan bertambahnya kadar protein yang ditunjukkan dengan persamaan $Y=43,82--0,81 x$. Jadi peranan sparing effect lemak dengan karbohidrat pada pakan tersebut telah dapat dilakukan. Keadaan ini memberikan peluang yang semakin besar bagi penyimpanan protein tubuh, yang mengakibatkan efisiensi dan retensi protein semakin baik.

Pada kandungan lemak pakan yang meningkat yaitu berturut-turut 2,75\%; 12,91\%; dan 18,59\% (Tabel $3)$, retensi lemaknya semakin menurun. Hal ini berarti bahwa bagian lemak pakan yang dikatabolisme untuk menghasilkan energi semakin meningkat dengan meningkatnya kadar protein pakan. Walaupun demikian kadar lemak yang baik yang dapat berfungsi sebagai protein sparing effect bersama-sama karbohidrat adalah 12,91\%.

Selama penelitian, kualitas media dipertahankan dalam kondisi stabil, terutama suhu dan oksigen. Untuk mempertahankan kestabilan suhu maka pada media dipasang heater, sehingga suhu stabil berkisar $27--28^{\circ} \mathrm{C}$. Media diberikan aerasi dengan cukup dan media dipelihara setiap hari dengan mengganti air sebanyak $2 / 3$ setiap 2 hari. Oksigen terlarut selama penelitian berkisar 6,5--7 mg/L dan pH 7--8.

Tabel 5. Performansi hasil penelitian benih baung pada rasio energi-protein $8 \mathrm{kkal} / \mathrm{g}$ protein untuk kadar protein berbeda

Table 5. Performance of the experiment result baung fry at energy-protein ratio $8 \mathrm{kcal} / \mathrm{g}$ protein for different protein level

\begin{tabular}{lccc}
\hline \multirow{1}{*}{$\begin{array}{c}\text { Parameter } \\
\text { Parameter }\end{array}$} & \multicolumn{3}{c}{$\begin{array}{c}\text { Perlakuan (kadar protein \%) } \\
\text { Treatment (protein level \%) }\end{array}$} \\
\cline { 2 - 4 } & 30 & 35 & 40 \\
\hline $\begin{array}{l}\text { Laju pertumbuhan harian (\%) } \\
\text { Daily growth rate (\%) } \\
\text { Efisiensi pakan (\%) }\end{array}$ & $6.66 \pm 0.84$ & $7.76 \pm 0.60$ & $7.09 \pm 1.14$ \\
$\begin{array}{l}\text { Feed efficiency (\%) } \\
\text { Rasio efisiensi protein }\end{array}$ & $33.71 \pm 4.63$ & $50.24 \pm 1.29$ & $49.56 \pm 4.86$ \\
$\begin{array}{l}\text { Protein efficiency ratio } \\
\text { Retensi protein (\%) }\end{array}$ & $1.21 \pm 0.01$ & $1.44 \pm 0.04$ & $1.24 \pm 0.12$ \\
$\begin{array}{l}\text { Protein retention (\%) } \\
\text { Retensi lemak (\%) } \\
\begin{array}{l}\text { Fat retention (\%) } \\
\text { Sintasan (\%) }\end{array} \\
\text { Survival rate (\%) }\end{array}$ & $19.67 \pm 2.42$ & $25.16 \pm 0.89$ & $21.63 \pm 1.87$ \\
\hline
\end{tabular}


Berdasarkan laju pertumbuhan biomassa harian, efisiensi pakan, rasio efisiensi protein, retensi protein, dan lemak dari hasil penelitian I (6 kkal/g protein) dan penelitian II (8 kkal/g protein), menunjukkan pakan berkadar protein $35,79 \%$ dengan rasio energiprotein $8 \mathrm{kkal} / \mathrm{g}$ protein memberikan respon terbaik bagi benih baung.

\section{KESIMPULAN}

Dari penelitian ini dapat disimpulkan bahwa untuk pertumbuhan optimal benih baung diperlukan pakan berkadar protein $35 \%$ dengan rasio energi-protein 8 $\mathrm{kkal} / \mathrm{g}$ protein. Kadar protein tersebut dapat digunakan sebagai dasar untuk pembuatan pakan benih baung.

\section{DAFTAR PUSTAKA}

Cowey, C.B. and J.R. Sargent. 1972. Fish nutrition. Ad. Mar. Biol. 110:383--392.

De Silva, S.S. and Trevor A. Anderson. 1995. Fish Nutrition in Aquaculture. Chapman \& Hall Aquaculture Series 1. 308 pp.

Gaylord, T.Gibson, and Delbert M. Gatlin III. 2001. Dietary protein and energy modification to maximize compensatory growth of channel catfish (/chtalurus punctatus). Aquaculture, 194:337--348.

Huisman, E.A. 1976. Food conversion efficiencies at maintenance and production levels for carp, Cyprinus carpio, and rainbow trout, Salmo gairdneri Richardson. Aquaculture, 9:259--273.

Hernandez, M.D., M.A. Egea, F.M. Rueda, F. Aguado, F.J. Martinez, and B. Garcia. 2001. Effects of commercial diets with different $P / E$ ratios on sharpsnout seabream (Diplodus puntazzo) growth and nutrient utilization. Aquaculture, 195:321--329.

Khans, M.S., K.J. Ang, M.A. Ambak, and C.R. Sat. 1973. Optimum protein requirement of a Malaysian freshwater catfish (Mystus nemurus). Aquaculture, 112:227--235.
Lovell, T. 1980. Feeding tilapia. Aquaculture, 7:42--43.

Mokoginta, I., M.A. Suprayudi, dan M. Setiawati. 1995. Kebutuhan optimum protein dan energi pakan benih ikan gurame (Osphronemus gouramy Lac.). J. Pen. Per. Indonesia. 1(3):82--95.

National Research Council (NRC). 1977. Nutrient Requirement of Warmwater Fishes. National Academy Press, Washington D.C. $78 \mathrm{pp}$.

National Research Council (NRC). 1983. Nutrient Requirement of Warmwater Fishes and Shellfish. National Academy Press, Washington D.C. 78 pp.

Sandra, H. 2002. Pengaruh Kadar Vitamin C Pakan Bentuk L-Ascorbyl-2-Phosphate Magnesium yang Berbeda terhadap Kemampuan Tubuh Mengatasi Stres dan Pertumbuhan Ikan Baung (Mystus nemurus $C$. V.). Tesis Program Pascasarjana. Institut Pertanian Bogor. 76 pp.

Suryanti, Y. 2002. Perkembangan Aktivitas Enzim Pencernaan dan Hubungan dengan Kemampuan Pemanfaatan Pakan Buatan Pada Larva/Benih Ikan Baung (Mystus nemurus C.V.). Tesis Magister Sains, Program Pascasarjana, Institut Pertanian Bogor, Bogor. 46 pp.

Sveier, H., Wathne, E., and Lied, E. 1999. Growth, feed and nutrient utilization and gastrointestinal evacuation time in Atlantic Salmon (Salmo salar L.); the effect of dietary fish meal partcle size and protein concentration. Aquaculture, 180: 265--282.

Tang, U.M. 2000. Kajian Biologi, Pakan, dan Lingkungan pada Awal Daur Hidup Ikan Baung, Mystus nemurus (Cuvier \& Valenciennes, 1945). Disertasi. Program Pascasarjana Institut Pertanian Bogor, Bogor. 118 pp.

Viola, S. and U. Rappaport. 1979. The extra calory effect of oil in the nutrition of carp. Bamidgeh, 31:51--68.

Wilson, R.P. 1985. Postpandrial changes in serum amino acid of channel catfish fed diets containing different level of protein and energy. Aquaculture, 49:101--110.

Watanabe, T. 1988. Fish Nutrition and Mariculture. Department of Aquatic Biosciences. Tokyo University of Fisheries. JICA. 223 pp. 